\title{
TUTURAN BESIPUNG SUKU PASER PEMATANG KABUPATEN PASER KALIMANTAN TIMUR DITINJAU DARI ASPEK PUISI LAMA DAN NILAI BUDAYA
}

\author{
Mursalim \\ Fakultas Ilmu Budaya Universitas Mulawarman \\ E-mail: mursalim.unmul@yahoo.com
}

\begin{abstract}
Abstrak
Bangsa Indonesia adalah bangsa yang besar, bangsa yang terdiri dari berbagai suku dan latar belakang budaya yang beraneka ragam. Keanekaragaman itu ditandai dengan kehidupan sosial budaya yang khas dari setiap suku.Kekhasan inilah yang meliputi semua aspek kehidupan latar belakang kebudayaan.Seperti suku bangsa lainnya di daerah Paser juga memiliki kekayaan budaya adat istiadat, dan seni. Namun, kekayaan yang dimiliki oleh suku Paser tersebut tidak terlalu dikenal oleh masyarakat luas, sehingga dikuatirkan akan tergeserkan dengan budaya modern, terutama upacara budaya pengobatan besipung. Itulah sebabnya peneliti mencoba meneliti penelitian yang berjudul "Tuturan Besipung Suku Paser Pematang Kabupaten Paser Kalimantan Timur Ditinjau dari Aspek Puisi Lama dan Nilai Budaya.Tujuan penelitian adalah untuk memberikan informasi kepada masyarakat pembaca mengenai tuturan besipung Suku Paser ditinjau dari aspek puisi lama dan nilai budaya.Metode penelitian yang digunakan dalam penelitian ini adalah penelitian deskriptif yaitu mendeskripsikan dan mendokumentasikan upacara besipung suku Paser ditinjau dari aspek puisi lama dan nilai budaya. Selanjutnya aspek-aspek materi yang akan dipaparkan dari hasil penelitian dalam penulisan makalah ini adalah seperti berikut: (1) pendahuluan, (2) pembahasan dan uraian yang meliputi; bentuk tuturan Besipung Suku Paser ditinjau dari aspek puisi lama; hubungan upacara Besipung Suku Paser dengan nilai-nilai budaya, (3) penutup.
\end{abstract}

Kata kunci: Tuturan Besipung, Suku Paser, puisi lama, nilai budaya

\section{PENDAHULUAN}

Bangsa Indonesia adalah bangsa yang besar. Bangsa yang terdiri dari berbagai suku dan latar belakang budaya yang beraneka ragam. Keanekaragaman itu ditandai dengan kehidupan sosial budaya yang khas setiap suku. Kekhasan inilah yang meliputi semua aspek kehidupan latar belakang kebudayaan, seperti suku bangsa lainnya, di daerah juga memiliki kebudayaan, budaya adat istiadat, dan seni.

Selanjutnya, Dananjaya,(1986;2) menjelaskan bahwa,"Tuturan adalah sebagian kebudayaan yang kolektif terbesar dan diwariskan secara turuntemurun, di antara kolektif macam apa saja secara tradisional dalam versi berbeda, baik dalam bentuk lisan maupun contoh yang disertai dengan gerak isyarat atau alat bantu pengingat.

Sastra lisan dianggap sebagai bentuk sastra pertama, hal ini tidak hanya diakui oleh ahli kesusastraan Indonesia saja tapi juga di dunia. Karya sastra telah tercipta jauh sebelum nenek moyang kita mengenal aksara untuk menuliskan kembali apa yang telah mereka ceritakan, sehingga penyebarannya dilakukan secara lisan atau oral.

Kemudian, ditambahkan oleh Koentjaraningrat (1984:3) bahwa suatu sistem nilai budaya terdiri atas konsepsi-konsepsi yang hidup dalam alam pikiran sebagian besar warga masyarakat mengenai hal-hal yang harus mereka anggap sangat bernilai 
dalam hidup.Oleh karena itu, suatu sistem nilai budaya biasanya berfungsi sebagai pedoman tertinggi bagi kelakuan manusia.Sistem tata kelakuan manusia yang tingkatnya lebih konkret seperti aturan-aturan khusus, hukum, dan nilai budaya tersebut.

Satra lisan jika dikaitkan dengan puisi lama, maka dalam puisi lama terdapat beberapa jenis seperti pantun, talibun, gurindam, syair, seloka, dan mantra.Selanjutnya, dilihat dari segi ciricirinya tuturan Besipung dapat dikategorikan dalam puisi lama jenis mantra. Mantra merupakan puisi yang berupa gubahan bahasa yang diresapi oleh kepercayaan akan dunia gaib. Irama bahasa sangatlah dipentingkan dengan maksud menciptakan nuansa magis.Mantra timbul dari hasil imajinasi atas dasar kepercayaan animisme. Untuk mempetajam pemahaman perihal mantra, Danandjaya dalam Lisana, (2015:22) menambahkan bahwa ciri-ciri mantra, (1) terdiri dari beberapa rangkaian kata berirama, (2) bersifat lisan, (3) lebih bebas dibandingkan dengan puisi rakyat lainnya dalam hal suku kata, baris, dan persajakan, (4) mantra diamalkan dengan memiliki tujuan tetentu, yaitu untuk mendapatkan kekuatan dari dewa, Tuhan (bagi yang beragama), dan makhluk lainnya, serta untuk membujuk atau mengusir roh jahat dan mengobati orang sakit.

Upacara Besipung adalah bentuk upacara dan budaya Suku Paser Kalimantan Timur khususnya Suku Paser Pematang untuk menyembuhkan penyakit berat seperti orang sakit yang dikirim melalui makhluk halus, dan mengusir rohroh jahat.Besipung juga termasuk pengobatan tradisional yang sudah jarang digunakan yang mungkin terhadap penyakit-penyakit fatal.Upacara Besipung ini dilakukan pada malam hari dan hanya dilaksanakan pada malam hari saja.

Dengan mengacu kepada makna uraian tersebut, maka peneliti melaksanakan penelitian yang berjudul, "Tuturan Besipung Suku Paser Pematang Kabupaten Paser, Kalimantan Timur. Ditinjau dari Aspek Puisi Lama dan Nilai Budaya.

Kemudian, mengenai aspek materi yang akan diuraikan dalam makalah ini adalah (1) pendahuluan, (2) metodologi, (3) pembahasan, yang meliputi; bentuk tuturan Besipung ditinjau dari aspek puisi lama, dan hubungan Upacara Besipung dengan nilai-nilai budaya, (3) simpulan.

\section{METODOLOGI PENELITIAN}

Metode Penelitian yang digunakan dalam penelitian ini adalah metode penelitian deskriptif. Penelitian deskriptif mempelajari masalahmasalah dalam masyarakat, serta tata cara yang berlaku dalam masyarakat serta situasi-situasi tertentu, termasuk tentang hubungan kegiatan, sikap, pandangan, serta proses-proses yang sedang berlangsung dan pengaruhdari suatu fenomena. Selanjutnya, penelitian ini juga termasuk jenis penelitian diskriptif yaitu mendeskripsikan dan mendokumentasikan upacara Besipung Suku Paser, ditinjau dari bentuk puisi lama dan nilainilai budaya.Selanjutnya, teknik pengumpulan data, yaitu mengumpulkan data upacara Besipung melalui observasi, wawancara, rekaman, dan foto pendokumentasian.

\section{PEMBASAHAN}

\section{A. Bentuk Tuturan Besipung Ditinjau dari Aspek Puisi Lama}

1. Tuturan upacara Besipung terdiri rangkaian kata yang berirama dan memiliki tujuan tertentu. Jumlah bait dalam tuturan tersebut memang tidak terbatas dan tidak terikat seperti puisi rakyat lainnya. Untuk lebih jelasnya, dapat dilihat pada contoh seperti berikut.

Jum kemikun na kun setana

Ingat-ingat saudara siku-siku

Jum kemikun na kum setana

Ingat-ingat saudara siku-siku

Sumber: Iswahyudi

Dalam kutipan tuturan tersebut, menunjukkan satu bait terdiri 6 baris, dalam setiap baris berirama akhir yang sama seperti berikut.

Baris pertama berakhiran $|\mathrm{a}|$ setana

Baris kedua berirama $|\mathrm{u}|$ siku-siku

Baris ketiga berirama |a| setana 
Baris keempat berirama $|\mathrm{u}|$ siku-siku

Baris kelima berirama $|\mathrm{a}|$ setana

Baris keenam berirama $|\mathrm{u}|$ siku-siku

Dari beberapa baris dalam satu bait dalam tuturan di atas mengalami perulangan pada baris pertama akandiulang pada baris ketiga, kelima, sedangkan pada baris kedua akan diulang pada baris keempat dan baris keenam. Semuanya berirama sama yaitu a-u-a-u-a-u. Selanjutnya, pada tuturan lain ada yang terdiri dari tiga baris.

\section{Contoh :}

Siru muli kesisik daring dayang

Ruko langa nyolis diang

Bulan sayang

Sumber: Iswahyudi

Tuturan di atas menunjukkan satu bait terdiri dari tiga baris, dan berirama akhir sama seperti berikut.

Baris pertama berakhiran |ang| (dayang)

Baris kedua berakhiran |ang| (diyang)

Baris ketiga berakhiran |ang| (sayang)

Dari beberapa baris dalam satu bait tuturan di atas semuanya berirama ang-ang-ang.

\section{Tuturan Besipung Bersifat Lisan}

Tuturan atau mantra umumnya bersifat lisan. Begitu juga tuturan upacara Besipung bersifat lisan karena diucapkan atau dituturkan secara langsung oleh datu atau dukun pada saat upacara Besipung. Selanjutnya, tuturan Besipung yang dilisankan oleh datu dituturkan secara turun-temurun hingga sekarang sebagai warisan milik bersama yang harus dijaga dan dilestarikan.

Berikut contoh mantra Besipung yang sifatnya diturunkan oleh datu atau dukun.

\section{Tuturan Pertama}

Jum kemikun na kum setana Ingat-ingat saudara siku-siku Jum kemikun na kum setana Ingat-ingat saudara siku-siku Jum kemikun na kum setana
Ingat-ingat saudara siku-siku

Sumber: Iswahyudi

Makna tuturan di atas:

Penyakit seperti saudara

Bagaimana saudara tidak

Saling mengganggu

Datang tak diundang dan

Pulang tak diantar

\section{Tuturan Kedua}

Siru muli karisik daring dayang

Ruko langa nyolis diang

Bulau saying

Sumber: Iswahyudi

Makna tuturan tersebut adalah orang yang tidak mengganggu kembali jika masih seperti emas karena aku seperti emas.

Selain makna tuturan tersebut juga memiliki tujuan yaitu agar makhluk gaib tersebut tidak mengganggu makhluk hidup seperti manusia.Jadi, jika ditinjau dari aspek fungsi tuturan Besipung adalah untuk mengobati orang sakit sekaligus mengusir roh-roh jahat yang mengganggu makhluk hidup seperti manusia.

3. Upacara Besipung sebagai Sarana Tolong Menolong

Sebagai tujuan utama pelaksanaan upacara Tuturan Besipung adalah untuk memberikan pertolongan kepada orang yang ingin berobat. Upacara Besipung dapat terlaksana jika segala sesuatu yang menjadi syarat dalam upacara tersebut sudah dapat terpenuhi.Syarat-syarat upacara Tuturan Besipung Paser Pematang disebut soyong dan berupa tuturan yang diciptakanoleh masyarakat Suku Paser dengan menggunakan Bahasa Paser.Selanjutnya, bahan-bahan sesajen yang digunakan seperti bahan makanan yang berupa benda-benda seperti daun sirih, kapur, kelapa, gula merah, benang, jarum, gambir, dan tembakau, serta menggunakan dupa yang disebut karembulu. Karembulu berasal dari kayu keras yang mengeluarkan aroma wangi-wangian tajam. Jika tidak terpenuhi hal-hal tersebut di atas, 
tidak jadilah upacara dan tidak tercapailah tujuan upacara tersebut, dan jika upacara Besipung diadakan, maka dilaksanakan di ruangan tanpa sedikit pun cahaya.

\section{B. Nilai-nilai Budaya pada Upacara Besi- pung}

Nilai budaya dalam hubungan manusia dalam masyarakat adalah nilai-nilai yang berhubungan dengan kepentingan para anggota masyarakat. Adapun nilai-nilai budaya yang dapat diperoleh pada pelaksanaan upacara Tuturan Besipung Suku Paser adalah nilai budaya yang mengacu kepada nilai moralitas seperti berikut.

\section{a. Kerukunan}

Masyarakat Suku Paser terdapat berbagai macam etnis, salah satunya suku Paser Pematang. Upacara Besipung adalah kebiasaan yang melekat pada jiwa masyarakat Suku Paser Pematang, sehingga mereka akan saling membantu satu sama lain pada saat keluarga ataupun tetangga yang terkena penyakit nonmedis akan disembuhkan oleh upacara Besipung yang akan dipimpin oleh datu. Di situlah mereka menjalin erat tali persaudaraan dan menambah kerukunan untuk sesama lainnya.

\section{b. Kepatuhan}

Upacara Besipung diyakini oleh Suku Paser Pematang sejak zaman nenek moyang mereka terdahulu. Mereka mematuhi apa yang telah diperintahkanoleh adat dan budaya baik dalam diri maupun dalam lingkungan mereka.

\section{c. Menghormati Sesama}

Upacara Besipung adalah upacara yang dilaksanakan oleh banyak orang dan berfungsi sebagai pengobatan. Diketahui bahwa seseorang yang melakukan upacara Besipung, mereka saling menghormati kepada sesama yang mempunyai hajat. Dengan adanya kebiasaan, mereka saling menghormati kepada siapapun di sekeliling mereka.

\section{KESIMPULAN}

Berdasarkan hasil temuan/pembahasan pada makalah ini, maka hal yang dapat disimpulkan adalah sebagai berikut.
1. Upacara Besipung hanya dapat dilaksanakan oleh datu yang memang berprofesi sebagai pembawa upacara Besipung.

2. Pola Tuturan Upacara Besipung terdapat penggunaan kata terdiri dari 3 - 15 kata, dan kata-kata yang terdapat dalam upacara Besipung adalah kata yang menasehati, tidak mengganggu manusia atau pasien.

3. Isi Tuturan Upacara Besipung dapat berupa bentuk mantra, dan didukung berirama abc-abc, abcd-abcd, abcde-abcde, dan bersifat lisan serta bertujuan tertentu yang berhubungan dengan kekuatan gaib.

4. Fungsi Upacara Besipung untuk mengobati orang sakit, mengusir roh jahat, dalam penyembuhan masyarakat setempat.

5. Nilai budaya pada upacara Besipung adalah bernilai moralitas yang meliputi menghormati sesama, kepatuhan, dan kerukunan.

\section{DAFTAR PUSTAKA}

Alfan, (Editor). 1985. Kritik Sastra : Sebuah Pengantar. Jakarta : Gramedia

Bakry, Y. Sastri. 2003. Ensiklopedia Sastra Indonesia. Bandung : Penerbit Titian Ilmu.

Danandjaja, James. 1991. Tentang Sastra. Terj. Achadiati Ikram. Jakarta: Intermasa.

Depdiknas.2005. Kamus Besar Bahasa Indonesia. Jakarta: Gramedia Pustaka Utama

Esten, Mursal. 1999. Kajian Transfirmasi Budaya. Bandung: Angkasa.

Koentjaraningrat. 1990. Kebudayaan, Mentalis dan Pembangunan. Jakarta: PT. Publishing.

Koentjaraningrat.1986. Pengantar Metodologi Research Sosial. Yogyakarta: Media Pressindo.

Kosasih, E. 2012. Dasar-Dasar Keterampilan Bersastra. Bandung: CV. Vyrama Widya.

Leech, Geofrey. 1993. Prinsip-Prinsip Pragmatik. Jakarta: Universitas Indonesia.

Rizal, Yoce. 2010. Apresiasi Puisi dan Sastra Indonesia. Jakarta: Grafika Mulia.

Soermardjan, Selo. 1984. Budaya Sastra Indonesia. Jakarta: CV Rajawali.

Teeuw, A. 1995.Sastra dan Ilmu Sastra: Pengantar Teori Sastra. Jakarta: Pustaka Jaya. 